\title{
Penggunaan Algoritma Floyd-Warshall untuk Menentukan Rute Terpendek Menuju Air Terjun Waimarang
}

\author{
Fatmawati Ridwan ${ }^{1)}$, Ririn Dwi Agustin ${ }^{2)}$ \\ ${ }^{1,2)}$ IKIP Budi Utomo Malang \\ Email: fatmawatiridwan619@gmail.com, ririndwiagustin@budiutomomlang.com
}

\begin{abstract}
The Floyd-Warshall algorithm is a method that performs solutions by looking at the solution to be obtained as an interrelated decision. The algorithm invented by Warshall to find the shortest route. This type of research is descriptive qualitative research with a case study approach. A case study examines a particular case or phenomenon in society which is carried out in depth to study the background, circumstances and interactions that occur. The result of this research is to get the shortest route to Waimarang Waterfall using the Floyd-Warshall Algorithm in East Sumba. The initial stage of the search for the Shortest Route is to find the routes that lead to Waimarang Waterfall with less distance, time and cost. The points are then connected to each other according to the road traversed by the vehicle so that it becomes a lane. Then the path that has been formed is made a neighborhood matrix and calculated using the Floyd-Warshall Algorithm so that the shortest path option is obtained.
\end{abstract}

Keywords : Floyd-Warshall Algorithm, Shortest Route

\begin{abstract}
ABSTRAK
Algoritma Floyd-Warshall yaitu metode pemecahan masalah dengan memandang solusi yang diperoleh sebagai keputusan yang saling terkait. Algoritma yang ditemukan Warshall ini untuk mencari rute terpendek. Jenis penelitian ini adalah kualitatif deskriptif dengan pendekatan studi kasus. Studi kasus meneliti kasus tertentu yang ada di dalam masyarakat yang dilakukan secara mendalam untuk mempelajari latar belakang, keadaan dan interaksi yang terjadi. Hasil penelitian ini adalah mendapatkan rute terpendek menuju Air Terjun Waimarang dengan menggunakan Algoritma Floyd-Warshall di Sumba Timur. Tahap awal dari pencarian Rute Terpendek yaitu dengan mencari rute-rute yang menuju ke Air Terjun Waimarang dengan jarak, waktu dan biaya yang lebih sedikit. Titik-titik yang ada kemudian saling dihubungkan sesuai dengan jalan yang dilewati oleh kendaraan sehingga menjadi suatu jalur. Kemudian jalur yang sudah terbentuk dibuat matriks ketetanggaan dan dihitung
\end{abstract}


menggunakan Algoritma Floyd-Warshall sehingga didapatkan pilihan jalur yang terpendek.

Kata kunci : Algoritma Floyd-Warshall, Rute Terpendek

\section{PENDAHULUAN}

Indonesia mempunyai potensi kekayaan alam yang banyak. Kekayaan alam tersebut jika dikelola dengan bagus dapat meningkatkan pertumbuhan ekonomi (Mulyadi, 2017). Salah satu sector kekayaan alam yang memiliki nilai ekonomi adalah dari sektor pariwisata. Pariwisata banyak diminati orang dan pariwisata dapat mengembangkan daya kreatif suatu individu (Asriandy, 2016).

Kabupaten Sumba Timur memiliki potensi di sektor pariwisata. Kabupaten Sumba Timur, Nusa Tenggara Timur merupakan salah satu destinasi liburan yang menyimpan segudang tempat wisata yang eksotis. Mulai dari perbukitan, padang rumput, pantai, dan wisata air terjun yang ada di sini. Wisata alam tersebut sangat menarik untuk dikunjungi. Kabupaten Sumba Timur memiliki Air Terjun Waimarang yang terletak di Melolo, Desa Watu Hadang, Kecamatan Umalulu Sumba Timur, NTT.

Perjalanan menuju ke wisata air terjun bisa menggunakan alat transportasi seperti motor atau mobil dari Kota Waingapu. Dari Kota Waingapu ke Air Terjun Waimarang dibutuhkan waktu sekitar 2 jam perjalanan dengan jalan yang bisa dibilang tidak cukup mulus (Ernawati, 2018). Masih ada jarak satu kilometer trekking menuju Air Terjun Waimarang. Sebelum sampai ke Air Terjun traveler juga harus melintasi sungai terlebih dahulu. Walaupun sedikit melelahkann perjuangan trekking akan terbayar dengan keindahan Air Terjun Waimarang (Prakoso, 2018).

Model rute terpendek adalah pemilihan solusi paling efisien dalam menghubungkan satu titik (node) dengan titik (node) yang lain (Siswanto, 2006:410). Terdapat algoritma yang dapat dimanfaatkan untuk memecahkan permasalahan rute terpendek yaitu algoritma Floyd-Warshall. Algoritma yang dikembangkan oleh Warshall ini merupakan algoritma yang mudah diterapkan (Ningrum, 2016). Az-Zahra (2017) menyatakan bahwa algoritma Floyd-Warshall berhasil dalam menemukan jarak terpendek. Setiawan, dkk (2017) juga menggunakan algoritma Floyd-Warshall dalam menemukan lintasan terpendek untuk mengangkut sampah. Muzdalifah rute 
terpendek dalam mendistribusikan barang. Dermawan (2019) mengatakan bahwa rute terpendek terbaik adalah menggunakan algoritma Floyd-Warshall.

\section{METODE PENELITIAN}

Penelitian ini merupakan jenis kualitatif, yakni penelitian dengan kondisi objek alam dan peneliti sebagai instrumen inti (Sugiyono, 2005). Pada penelitian ini menggunakan pendekatan studi kasus. Subjek dalam penelitian ini adalah Algoritma Floyd-Warshall untuk menentukan jalur terpendek. Penelitian ini dilakukan di Desa Watu Hadang, Kecamatan Umalulu Sumba Timur NTT dan pengumpulan data penelitian dilakukan pada selama 3 bulan.

Berikut akan diuraikan mengenai analisis masalahnya. Bagi wisatawan pendatang, masih ada yang belum mengetahui tentang wisata air terjun Waimarang. Sehingga saat ingin ke air terjun Waimarang, wisatawan malah melewati jalur yang panjang sehingga membuang tenaga, biaya dan waktu.

Mengidentifikasi masalah tersebut dapat menggunakan Algoritma FloydWarshall. Pertama dilakukan perancangan sistem pendukung keputusan. Berikut perancangan sistem keputusan yang digunakan.

a. Model

Model sistem untuk menemukan rute terdekat menuju air terjun Waimarang menggunakan model matematika atau kualitatif dengan menggunakan Algoritma Floyd-Warshall.

b. Data

Data yang diperlukan oleh sistem adalah jalan menuju air terjun waimarang.

c. Proses-Proses

Penggambaran proses yang terjadi pada sistem dibutuhkan pembuatan jalur dari data yang didapat untuk menuju ke air terjun.

d. Algoritma Floyd-Warshall

Pencarian rute terpendek dengan menggunakan algoritma Floyd-Warshall ini yaitu memulai iterasi dari titik awal kemudian memperpanjang rute dengan mengevaluasi titik-titik hingga sampai titik tujuan dengan jumlah seminimal mungkin. 
Selanjutnya adalah perancangan Algoritma Floyd-Warhall. Data Flow Diagram (DFD) adalah diagram yang menggunakan notasi-notasi untuk menggambarkan arus dari data system. DFD merupakan alat bantu dalam menggambarkan sistem yang berjalan logis.

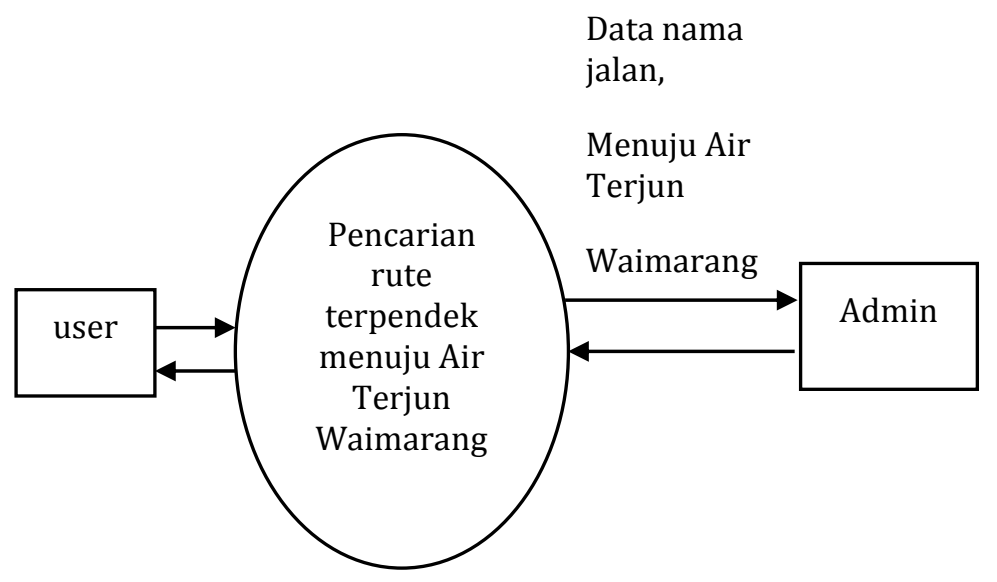

Gambar 1. Bagan Rute Terdekat manuju Air Terjun Waimarang

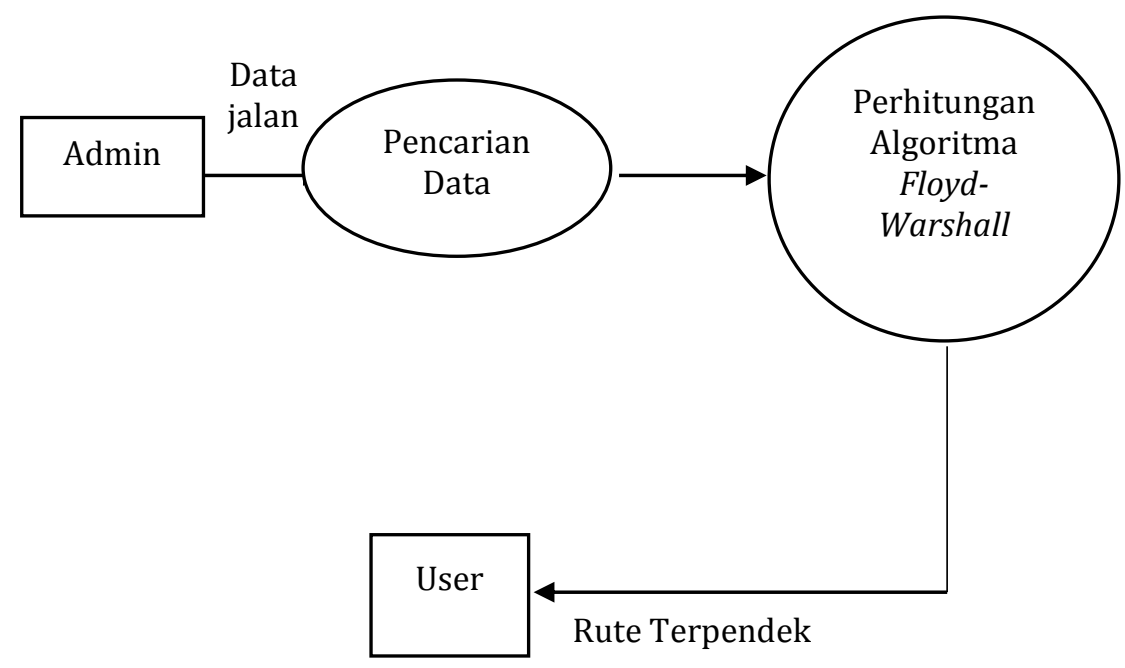

Gambar 2. Bagan DFD Level 1 Rute Terpendek Menuju Air Terjun Waimarang

\section{HASIL DAN PEMBAHASAN}

Berdasarkan hasil perhitungan dapat terlihat keseluruhan dari masing masing verteks setelah mengalami proses kalkulasi dengan pemanfaatan Algoritma Floyd-Warshall. Rute terpendek yang ditempuh dari A ke K adalah A - B - D - H - I - J - K dengan waktu tempuh 98 menit. Rute terpendek dari kota Waingapu (verteks 
A) menuju ke Air Terjun Waimarang (verteks K) adalah melalui Lampu Merah Payeti, Bank BRI Payeti, Pertamina Kambaniru, Umbu Mehang Kunda Airport, Melolo, Air Terjun Waimarang.

Semakin banyaknya tempat wisata di Sumba Timur pada saat ini, maka semakin banyak juga traveller yang ingin berkunjung ke Sumba Timur. Akan tetapi permasalahan - permasalahan yang terjadi pada saat ini adalah banyaknya jalur alternatif yang dapat dilewati untuk sampai ke lokasi. Tahap awal dari pencarian rute terpendek yaitu dengan mencari rute-rute yang menuju ke Air Terjun Waimarang dengan jarak, waktu dan biaya yang lebih sedikit.

Seusai didapatkan Node dan Path, akan diperoleh matriks $W_{i j}$ awal dan matriks $Z_{i j}$ awal. Matriks $W_{i j}$ awal merupakan matriks yang digunakan umtuk mencari rute terpendek setiap pasang titik, sedangkan matriks $Z_{i j}$ awal digunakan untuk mencari path terpendek antar titik. Matriks $W_{i j}$ awal dan $Z_{i j}$ awal lalu proses kalkulasi dengan Algoritma Floyd-Warshall untuk mendapatkan lintasan terpendek antara semua titik dalam rute tersebut. Kemudian perhitungan dilakukan hingga iterasi terakhir, maka didapatkan matriks $\mathrm{W}^{*}$ akhir hasil dari proses perhitungan Algoritma Floyd-Warshall yang menunjukkan jalur terpendek antara setiap titik dan matriks $Z^{*}$ akhir.

Kesimpulan dari hasil perhitungan matriks, kita dapat mengetahui jalur terpendek yang ditempuh untuk menuju ke Air Terjun Waimarang. Hasil yang didapat dari hasil perhitungan menggunakan Algoritma Floyd-Warshall memberikan pilihan rute perjalanan yang lebih efektif dan efisien dilihat dari jarak. Berikut rute terpendek dari kota Waingapu ke air terjun Waimarang.

a. Titik A merupakan node awal keberangkatan dan verteks tujuan adalah ke titik K. maka titik awal diberi nilai dengan nilai 0 .

b. Algoritma Floyd-Warshall akan melakukan kalkulasi terhadap node yang terhubung langsung dengan node keberangkatan (node A), dan hasil yang didapat adalah node B karena hanya ada satu node yang terhubung dengan node A. nilai $(0+3)=3$.

c. Node B ditentukan sebagai node keberangkatan dan ditandai sebagai node terjamah. Selanjutnya Algoritma Floyd-Warshall akan melakukan kalkulasi kembali terhadap node - node yang terhubung langsung dengan node yang telah terjamah. Dan kalkulasi FloydWarshall menunjukkan bahwa node D yang menjadi node keberangkatan selanjutnya karena mempunyai nilai bobot yang paling kecil yaitu 5 . Total node yang telah terjamah adalah $\mathrm{A}-\mathrm{B}-\mathrm{D}$ dengan nilai $(0+3+5)=8$. 
d. Perhitungan berlanjut dengan node D ditandai sebagai node yang telah terjamah. FloydWarshall akan melakukan kalkulasi kembali terhadap node yang telah terhubung langsung dengan node yang telah terjamah. Dan kalkulasi Floyd-Warshall menunjukkan bahwa node $\mathrm{H}$ yang menjadi node keberangkatan selanjutnya karena mempunyai nilai bobot yang paling kecil yaitu 10 . Total node yang telah terjamah adalah $\mathrm{A}-\mathrm{B}-\mathrm{D}-\mathrm{H}$ dengan nilai $(0+3+5+10)=18$

e. Node $\mathrm{H}$ ditandai sebagai node yang telah terjamah. Floyd-Warshall akan melakukan kalkulasi kembali terhadap node yang telah terhubung langsung dengan node yang telah terjamah. Dan kalkulasi Floyd-Warshall menunjukkan bahwa node I yang menjadi node keberangkatan selanjutnya karena mempunyai nilai bobot yang paling kecil yaitu 10 . Total node yang telah terjamah adalah $\mathrm{A}-\mathrm{B}-\mathrm{D}-\mathrm{H}-\mathrm{I}$ dengan nilai $(0+3+5+10+10)=28$

f. Node I ditandai sebagai node yang telah terlewati. Floyd-Warshall melakukan perhitunagn lagi terhadap node yang telah terhubung langsung dengan node yang telah terlewati. Perhitungan Floyd-Warshall menunjukkan bahwa node $\mathrm{J}$ yang menjadi node keberangkatan selanjutnya karena hanya ada satu node yang terhubung dengan node I dan nilai bobotnya yaitu 40 . Total node yang telah terjamah adalah $\mathrm{A}-\mathrm{B}-\mathrm{D}-\mathrm{H}-\mathrm{I}-\mathrm{J}$ dengan nilai $(0+3+5+10+10+40)=68$

g. Node $\mathbf{J}$ merupakan node yang telah terlewati. Floyd-Warshall melakukan perhitungan lagi terhadap node yang telah terhubung langsung dengan node yang telah terlewati. Perhitungan Floyd-Warshall menunjukkan bahwa node K menjadi node keberangkatan selanjutnya karena hanya node $\mathrm{K}$ yang terhubung dengan node $\mathrm{J}$ dan nilai bobotnya 30 . Total node yang telah terjamah adalah $\mathrm{A}-\mathrm{B}-\mathrm{D}-\mathrm{H}-\mathrm{I}-\mathrm{J}-\mathrm{K}$ dengan nilai $(0+3+5+10+10+40+30)=98$

\section{KESIMPULAN DAN SARAN}

Rute terpendek menuju Air Terjun Waimarang dengan menggunakan Algoritma Floyd-Warshall di Sumba Timur adalah sebagai berikut. Tahap awal dari pencarian rute terpendek yaitu dengan mencari rute-rute yang menuju ke Air Terjun Waimarang dengan jarak, waktu dan biaya yang lebih sedikit. Titik - titik yang ada kemudian saling dihubungkan sesuai dengan jalan yang dilewati oleh kendaraan sehingga menjadi suatu jalur. Kemudian jalur yang sudah terbentuk dibuat matriks ketetanggaan dan dihitung menggunakan Algoritma Floyd-Warshall sehingga 
didapatkan pilihan jalur yang terpendek. Berdasarkan hasil perhitungan dapat terlihat keseluruhan dari masing - masing verteks setelah mengalami proses kalkulasi dengan menggunakan Algoritma Floyd-Warshall. Jalur terpendek yang ditempuh dari A ke K adalah $\mathrm{A}-\mathrm{B}-\mathrm{D}-\mathrm{H}-\mathrm{I}-\mathrm{J}-\mathrm{K}$ dengan waktu tempuh 98 menit. Atau pada dunia nyatanya, rute terpendek dari kota waingapu (verteks A) menuju ke Air Terjun Waimarang (verteks K) adalah melalui Lampu Merah Payeti, Bank BRI Payeti, Pertamina Kambaniru, Umbu Mehang Kunda Airport, Melolo, Air Terjun Waimarang.

Berdasarkan penelitian yang telah dilakukan, penulis sadar masih banyak kekurangan pada penulisan ini, maka adapun saran terkait penelitian ini. Penelitian ini disarankan untuk menggunakan data jalur yang lebih banyak lagi agar lebih banyak pilihan pada rute awal dan rute tujuan.

\section{REFERENSI}

Ammar, Chaedar dan Heri Suprapto. 2015. Penerapan Algoritma Floyd Warshall dalam Pencarian Rute Terpendek dan Tercepat pad Studi Kasus di Singapura hingga Thailand Selatan Berbasis Android. Jurnal Ilmiah Informatika Komputer, Vol. 20, No. 2.

Asriandy, Ian. 2016. Strategi Pengembangan Obyek Wisata Air Terjun Bissapu di Kabupaten Bantaeng. Skripsi. Makassar: Universitas Hasanuddin.

Az-Zahra, Rifqi R. 2017. Implementasi Algoritma Floyd Wharshall untuk Pencarian Jalur Terpendek Non Player Character (NPC) pada Game 3D Pembelajaran Kosa Kata Bahasa Arab. Skipsi. UIN Malang.

Dermawan, Tri Setya. 2019. Comparison of Djikstra dan Floyd-Wharshall Algorithm to Determine the Best Route of Train. International Journal on Informatics for Development. Vol. 7, No. 2.

Ernawati, J. 2018. Air Terjun Waimarang Bak Surga Tersembunyi dari Sumba Timur. (Online), https://www.viva.co.id/gaya-hidup/travel/1067238-air-terjunwaimarang-bak-surga-tersembunyi-dari-sumba-timur.

Muzdalifah, Lilik, Kresna O., Eka D.M. 2018. Model Jaringan Distribusi Beras Optimal Menggunakan Algoritma Floyd Wharshall. Jurnal Riset dan Aplikasi Matematika (JRAM), Vol. 2, No. 2.

Ningrum, Widya Friska dan Tatyantoro Andrasto. (2016). Penerapan Algoritma FloydWarshall Dalam Menentukan Rute Terpendek Pada Pemodelan Jaringan Pariwisata Di Kota Semarang. Jurnal Teknik Elektro Vol.8, No.1. 
Prakoso, J. R. 2018. Air Terjun Waimarang, Kolam Renang Alam dari Sumba Timur. (Online), https://ravel.detik.com/domestic-destination/d-4192708/air-terjun-waimarangkolam-renang-alam-dari-sumba-timur.

S, Mulyadi. 2017. Ekonomi Sumber Daya Manusia: Dalam Perspektif Pembangunan. Jakarta: Rajawali Press.

Setiawan, Vega, Mariatul K, Woro B.P. 2017. Analisis Algoritma Floyd Wharshall untuk Menentukan Lintasan Terpendek Pengangkutan Sampah. Buletin Ilmiah Math. Stat. dan Terapannya (Bimaster), 6(3), 221-230.

Siswanto. 2006. Operations Research Jilid 1. Jakarta : Erlangga.

Sugiyono. 2005. Memahami Penelitian Kualitatif. Bandung: CV. Alfabeta. 